IRSH 6I (2016), Special Issue, pp. 243-262 doi:I0.10I7/So0208590I60004I9 (C) 2016 Internationaal Instituut voor Sociale Geschiedenis

\title{
The Role of the State in Employment and Welfare Regulation: Sweden in the European Context
}

\author{
MAX KOCH \\ Lund University, Faculty of Social Sciences, \\ Socialbögskolan \\ Box 23, 22 I00, Lund, Sweden \\ E-mail:max.koch@soch.lu.se
}

\begin{abstract}
This article examines the changing role of the Swedish state in employment and welfare regulation in an environment that has become more market driven, commodified, and Europeanized. It begins with a theoretical reflection on the role of the state in capitalist development and a review of the recent debate on the spatiality of state regulation: the state as employer, redistributor, and arbiter, and as a shaper of employment relations and welfare. In the latter role, the state is conceptualized as employer, guarantor of employment rights, and procedural regulator, as intermediating neo-corporatist processes, as macroeconomic manager, and as welfare state. From this theoretical basis, the paper identifies changes in state employment and welfare regulation by comparing two periods: the original and mainly nationstate-based founding stage of the Swedish welfare and employment model as it developed after the 1938 Saltsjöbaden Agreement, and the period after Sweden's accession to the European Union in 1995 .
\end{abstract}

\section{INTRODUCTION}

The Global Collaboratory on the History of Labour Relations distinguishes four main categories of labour: non-working, reciprocal labour, tributary labour, and commodified labour. Though all of these categories can be empirically found at all times in the past 500 years and across space, attempts to theorize the link between the development of the capitalist mode of production, labour regimes, and employment relations ${ }^{I}$ have presupposed a long-term trend towards an increase in commodified and market-oriented labour at the expense of the other types. Empirically referring to capitalist core countries, Hagelstange called this 
trend "proletarianization". ${ }^{2}$ Throughout much of the nineteenth and twentieth centuries an increasing percentage of the working-age population found itself in a situation in which there was no alternative but to sell their labour power as a commodity to make ends meet. Commodification as "proletarianization" meant that tributary labour, despite its continuously important role in the capitalist peripheries, came to play a marginal role within capitalist centres, that much of the work that used to be carried out within the household became marketized, and that self-employment diminished. Labour in general came to be seen as largely synonymous with market- and profit-oriented labour, devaluing household, care, community, and voluntary work, while the non-working part of the population came to be defined in relation to the working part: as either too old or too young to be "economically active", too affluent to be in need of selling their labour power, or unemployed and unable to do so. However, capitalist "markets" have never in themselves created labour and employment regimes, but rather were always assisted and embedded through more or less far-reaching socio-economic regulation. ${ }^{3}$ The degree to which people were actually forced to sell their labour power as a (fictitious) commodity depended on the strength of societal counter movements ${ }^{4}$ and particularly the intermediating role of the state. As a result, much of recent capitalist development appears as waves of commodification, decommodification, and recommodification of labour relations, with states playing key roles in the process.

In conceptualizing the concrete roles of the state in shaping labour regimes and relations, this Special Issue of the International Review of Social History (IRSH) distinguishes between three capacities of the state (conqueror, employer, and redistributor/arbiter) and between two relationships (vis-à-vis its own subjects and those of other states). Taking the example of the recent history of Sweden, this paper focuses on state capacities as employer, redistributor, and arbiter, and, in terms of relationships, on taxation and welfare as well as on corresponding ideologies. Recent state theories have stressed the shift from demand- to supply-side economics and towards more market-oriented approaches in state strategies. ${ }^{5}$ With regard to the European Union (EU), this literature indicates that the state, the welfare state in particular, has moved towards a weaker commitment to collective rights and to a stronger emphasis on

\footnotetext{
2. Thomas Hagelstange, Die Entwicklung von Klassenstrukturen in der EG und in Nordamerika (Frankfurt am Main, I988).

3. Max Koch, Roads to Post-Fordism: Labour Markets and Social Structures in Europe (Aldershot, 2006).

4. Karl Polanyi, The Great Transformation: The Political and Economic Origins of Our Time (Boston, 1944).

5. Bob Jessop, The Future of the Capitalist State (Cambridge, 2002).
} 
individual rights and duties, ${ }^{6}$ particularly after the introduction of the European Employment Strategy (EES). Europeanization has also led to a rescaling of socio-economic regulation in general and state regulation in particular. Against this background, this paper is concerned with the question of how exactly state roles in shaping labour relations, employment, and welfare changed in Sweden after its accession to the EU and the introduction of the EES. It is based upon a theoretical discussion of the role of the state in capitalist development and the spatiality of state regulation. It further suggests several dimensions along which the state shapes employment and welfare and acts as arbiter between capital and labour. From this theoretical perspective, it then discusses transitions in state strategies in Sweden by comparing the post-Saltsjöbaden and postEU-accession periods.

\section{STATE ROLES IN CAPITALIST DEVELOPMENT, SPATIAL TARGETING, EMPLOYMENT RELATIONS, AND WELFARE}

This section discusses three key roles of the state as employer, arbiter, and redistributor. First, it addresses the general relationship of capitalist development and the state; secondly, it considers the different spatial levels or scales on which states may be active in shaping regulation; thirdly, it refers to the state's role in structuring employment relations and welfare.

\section{Capitalist development and the state}

In capitalist economies, processes of production and wealth creation are structurally separated from the political processes of exercising coercive power and administrative control. The Marxian tradition, in particular, has linked the autonomous existence of the state to the structural prerequisites of an economy based on the circulation of commodities. In order to exchange goods, individuals must "recognize one another reciprocally as proprietors". 7 This includes a "juridical moment" since exchange relations are possible only if the individuals acting are not prevented from entering into them by, for example, feudal rule. ${ }^{8}$ Equally, appropriating commodities through the use of force is not a legal or legitimate course of action. Hence, respect for the principle of equivalence in exchange relations

6. Gøsta Esping-Andersen, "Who is Harmed by Labour Market Regulations? Quantitative Evidence”, in Idem and Mario Regini (eds), Why Deregulate Labour Markets? (Oxford, 2000), pp. 66-98.

7. Karl Marx, Grundrisse: Foundations of the Critique of Political Economy (Harmondsworth, I973), p. 243.

8. Evgeny Pashukanis, Law and Marxism: A General Theory (London, 1978). 
depends on a formally independent institution that guarantees the legal and economic independence of the owners of commodities: their equality, legal security, and protection. In the case of an advanced division of labour, this guarantee cannot be ensured in accordance with common law but must be institutionalized in an independent third party that, above all, monopolizes the legitimate use of physical force: ${ }^{9}$ the modern state. Hence, unlike pre-capitalist societies where monetary exchange relations play a minor role, the first general role of the state in capitalist development under the rule of law is to guarantee private property, the principle of equivalence, and the legal security of its economic subjects.

Exchange relations, however, are not reduced to the exchange of material features of use values. They also reproduce social relationships, which involve power asymmetries and social inequalities. The latter originate in different societal domains and take the form of class, race, religion, linguistic, or gender characteristics. In a social structure based on a dynamic plurality of exploitative and exclusionary relationships, ${ }^{10}$ the state is the main location for the political regulation of conflicts and for the maintenance of social order. ${ }^{\text {II }}$ Since, without state regulation, such a society would disintegrate, the second general role of the state is that of an arbiter to maintain a minimum of social cohesion and, at the same time, to legitimize remaining inequalities. Taxation is the main political means by which the state redistributes primary incomes for these purposes.

In its third role in capitalist development, the state has an indispensable capability of temporarily harmonizing conflicting group interests and creating consensus. ${ }^{12}$ A key issue in any capitalist society is the degree and the kind of commodification of socio-economic relations. It is far from being taken for granted, and indeed a controversial matter, what kind of private and social services and use values should take commodity form ${ }^{\mathrm{I} 3}$ and be sold and bought on markets that states often have to regulate. Childcare, elderly care, education, the regulation of prostitution as well as of carbon emissions are prominent recent examples of this conflict. The state appears here as an autonomous political sphere, where social classes and groups represent their interests in indirect and mediated ways. As political parties and interest groups raise variable issues, such as religion, age, and the environment, these interests and issues sometimes become the focus of government action, only to be superseded by others at later points

9. Max Weber, "Politics as a Vocation", in Hans Gerth and C. Wright Mills (eds), From Max Weber: Essays in Sociology (London, I991), pp. 77-1 28, 78.

ı. Koch, Roads to Post-Fordism, pp. I3-I6.

I I. Claus Offe, Contradictions of the Welfare State (London, I984).

I2. Alexander Gallas et al. (eds), Reading Poulantzas (London, 20I I).

I 3. This includes the issue of the conditions under which "non-working" is seen as legitimate. 
in time. ${ }^{14}$ State policies cannot be reduced to the strategic interests of single actors, but rather develop as a result of the heterogeneity and changing dynamics of social forces that influence state institutions. The nature of the composition of social forces, which are able to influence state policies in particular historical configurations, cannot be defined in general terms but must be explored empirically. Once such a coalition of relatively powerful actors is formed and has managed to influence the general direction of the state's policies, it takes the character of a relatively homogenous social phenomenon and appears to "act" as if it were a single actor: the more socially coherent the coalition of forces that influences the state, the fewer the contradictions across its policies. ${ }^{\mathrm{IS}}$ Hence, the state is an object of agency of the sociopolitical coalition that creates and recreates it, and, at the same time, a powerful actor, whose policies shape a range of societal fields. It is, to borrow Bourdieu's terms, structured and structuring at the same time.

\section{State spatiality}

The historical development of markets and capital tends to dissolve previously isolated communities and to regroup their inhabitants according to new spatio-temporal structures. In most parts of Europe in the nineteenth and twentieth centuries these largely followed the borders of the developing nation states. Towards the end of the twentieth century, however, this particular state territoriality began to be faced with Europeanization and internationalization, but also with localization processes that undermined this spatial arrangement. As a consequence, scholars ceased to presuppose a static concurrence of nation and state and began to view state spatiality in more dynamic ways. The spatial dimension of state regulation is not seen as a fixed object but as a delicate structure that is permanently subject to rescaling processes in the course of which new, multi-scalar structures of state organization, political authority, and socioeconomic regulation emerge. ${ }^{16}$ State institutions are foremost in what Brenner calls "spatial targeting": attempts to "enhance territorially specific locational assets, to accelerate the circulation of capital, to reproduce the labour force, to address place-specific socio-economic problems and/or to maintain territorial cohesion". ${ }^{17}$ Similarly, the notion of "spatio-temporal

I4. Max Koch and Martin Fritz, "Building the Eco-Social State: Do Welfare Regimes Matter?", Journal of Social Policy, 43 (2014), pp. 679-703.

I s. Nicos Poulantzas, State, Power, Socialism (London, 1978).

I6. J. Rogers Hollingsworth and Robert Boyer, Contemporary Capitalism: The Embeddedness of Institutions (Cambridge, 1997); Yuri Kazepov, Rescaling Social Policies towards Multilevel Governance in Europe (Aldershot, 2010).

17. Neil Brenner, "Urban Governance and Production of New State Spaces in Western Europe, 1960-2000", Review of International Political Economy, I I (2004), pp. 447-488, 453. 
fixes" has been developed to reflect the fact that particular accumulation regimes correspond with particular scales of regulation or spatial boundaries (national, transnational, local), in which structural coherence is sought. Spatio-temporal fixes are associated with policy frameworks that target specific jurisdictions, places, and scales as focal points for state regulation in particular periods of time. How state strategies at European and national levels, for example, are linked to each other cannot be clarified in general theoretical terms but must be explored empirically.

From the mid-I970s the Fordist growth model, with its focus on the national level, came under pressure not only through various processes of deregulation and re-regulation, but also through rescaling processes that led to ongoing shifts in the sites, scales, and modalities of the delivery of state activities. In what Jessop summarizes as a "Schumpeterian workfare postnational regime", it is the increased importance of scales of intervention and regulation other than at the national level that moves into focus. New forms of statehood correspond to increasingly open economies, for which the creation of systemic or structural competitiveness is the overall goal. The result is a tendency towards the watering down of the national state apparatus whose tasks are reorganized on "sub-national, national, supranational, and translocal levels". ${ }^{18}$ At the same time, foreign agents and institutions become more significant as sources of domestic policy ideas, policy design, and implementation. To the extent to which the increasingly transnational processes of accumulation of capital require forms of regulation that extend beyond the borders and the capacities of individual states, governments somewhat in compensation for the loss of scope for intervention at national level - attempt to create or strengthen international regulatory systems, of which the EU is especially important. Far from being made redundant by the emergent international and European order, national governments belong to its key architects.

\section{Shaping labour relations, employment, and welfare}

The Global Collaboratory on the History of Labour Relations has highlighted key roles of the state in the provision and regulation of labour relations, employment, and welfare: as employer, arbiter, and redistributor. In the modern (welfare) state these roles take somewhat more specific forms:

- State as employer: This role can take the form of internal and direct public employment or, in its market-oriented variant, commodified, indirect, and external forms of economic activity. Indeed, in some countries the state continues to be the largest single employer, offering a great deal of job security. However, it often features more restrictive 
industrial relations than the private sector, partly because parts of the public workforce are not allowed to strike. As indirect and external employer, a lesser or greater number of jobs in the formally private sector is dependent on state strategies. Employment in the infrastructure, education, and health sectors, among others, may be provided by private actors, but it remains nevertheless linked to governments' strategic priorities as well as to spending and outsourcing decisions.

- As guarantor of employment rights and procedural regulator: Where labour power takes the form of a commodity, representatives of capital and labour need to negotiate its price and the conditions of its use. ${ }^{19}$ Since an individual employee can normally not negotiate with an employer on equal terms, in most countries the state sets legally binding minimum standards that must be respected in employment contracts. ${ }^{2 \circ}$ Governments have interpreted this role differently, emphasizing either collective rights or individual employment rights and obligations. Furthermore, the state normally defines the status, rights, and obligations of the labour market parties (legally defining who may negotiate collective agreements). This may involve compulsory mechanisms for collective employee representation at company and/or workplace level, and the obligation on management to inform and consult representatives on key business and personnel policies. The state may also have a crucial role in handling or avoiding breakdowns in collective bargaining. Most national industrial relations systems contain either voluntary or compulsory mechanisms of conciliation, mediation, and arbitration.

- As arbiter in intermediating corporatist or neo-corporatist processes and macroeconomic management: The state facilitates the political exchange between management and labour at different (local, national, European) levels. This can take "harder" forms of government regulation and/or "softer" forms of governance based on the diffusion of good practice and "steering". ${ }^{21}$ Furthermore, the state shapes labour markets and employment regimes through demand and/or supply management;

- As redistributor and welfare state: The extent to which labour power is "decommodified"22 and institutional protection of workers from total

19. Marx, Capital, ch. 8 .

20. Richard Hyman, "The State of Industrial Relations", paper presented at the Industrial Relations in Europe Conference, 3I August 2006 to 2 September 2006, Ljubljana.

2 I. Mark Stuart and Miguel Martínez Lucio, "A Bridge over Troubled Water: The Role of the British Advisory, Conciliation and Arbitration Service (ACAS) in Facilitating Labour-Management Consultation in Public Sector Transformation" (Cornell University ILR School Working Paper, January 2007), available at http://digitalcommons.ilr.cornell.edu/cgi/viewcontent.cgi?article $=\mathrm{I}_{00} \& \mathrm{~K}$ context=workingpapers, last accessed 6 September 2016; Paul Marginson and Keith Sisson, European Integration and Industrial Relations: Multi-Level Governance in the Making (Basingstoke, 2004). 22. Gøsta Esping-Andersen, The Three Worlds of Welfare Capitalism (Cambridge, I990). 
dependence for survival on employers is provided. Welfare regimes take different forms and vary, above all, in terms of the particular division of the private and public provision of labour, ${ }^{23}$ to which different forms and extents of taxation correspond. Relatively generous welfare regimes with an accordingly high extent of "decommodification" tend to strengthen the position of workers and facilitate the set up and maintenance of institutionally coordinated industrial relations, while less generous regimes often coincide with weakly coordinated and more "individualized" industrial relations systems. The forms and conditions that frame the relations between the state and individual welfare recipients are likewise subject to change and include top-down government approaches and more recent governance models in which the state is primus inter pares in wider networks of public, semi-public, and private actors.

\section{GROWTH STRATEGY, LABOUR REGIMES, WELFARE REGULATION, AND THE STATE: TWO PERIODS COMPARED}

How have the interpretations of these state roles, particularly as employer, arbiter, and redistributor, and especially its welfare function changed since the origins of the "Swedish model"? What roles did different scales (European, national, local) play in these shifts? And what were the main consequences of these shifts in state strategies for labour relations, employment, and welfare? This section compares two time periods: the original one following the Saltsjöbaden Agreement and the current one that started to take shape in the wake of the crisis of the early I990s and with Sweden's accession to the EU in 1995 .

\section{Growth strategy, employment, and welfare regulation after Saltsjöbaden}

Until the I980s, Sweden's industrial relations system was based on centralor national-level collective bargaining, which was designed to achieve wider normative goals such as full employment and wage equality. The wage determination process comprised central wage negotiations between employers' organizations (Svenska Arbetsgivareföreningen, SAF) and trade unions (Landsorganisationen i Sverige, LO), sector-level bargaining on the application and adjustment of the central agreements, as well as companylevel negotiations on any remaining details. ${ }^{24}$ However, the underlying

23. Wil Arts and John Gelissen, "Three Worlds of Welfare Capitalism or More? A State-of-theArt Report", Journal of European Social Policy, I 2 (2004), pp. I 37-1 58.

24. Victor A. Pestoff, Beyond the Market and State: Social Enterprises and Civil Democracy in a Welfare Society (Aldershot, 2004); Max Koch, "Wage Determination, Socio-Economic Regulation and the State”, European Journal of Industrial Relations, I I (2005), pp. 327-346. 
notion that economic action should reflect social responsibility and promote social cohesion was not always taken for granted. The first three decades of the twentieth century were characterized by severe conflicts between employers and workers. The frequency of strikes was higher in this period than in most other European countries. ${ }^{25}$ In this situation, the state, usually represented by Social Democratic governments, played an active and engaged role in bringing together employers' and employees' representatives. This resulted in the 1938 Saltsjöbaden Agreement, the institutional basis of the new socio-economic model. Subsequently, governments could withdraw from the management of wage bargaining, which was increasingly carried out in the form of bipartite bargaining between strong unions and a highly centralized employer organization. Instead, governments supported the general growth strategy through complementary labour market and welfare policies.

This division of labour between the labour market parties, on the one hand, and the state, on the other, was reflected especially in the 1956 wage agreement that is generally seen as a crucial step in the manifestation of a mode of regulation based on central bargaining between the SAF and LO. The socio-economic background to this was a booming economy, which led to maximum utilization of the workforce. However, serious sectoral and regional inequalities had remained and continued to generate wage competition that was not in the interests of the employers as a whole. The trade unions, on their part, also wanted to avoid excessive wage disparities at the company, regional, and sector levels and therefore favoured central bargaining with the paramount goal of reducing these inequalities. ${ }^{26}$ Wage levels were not supposed to reflect the competitive situations of particular companies and sectors, but rather the general balance of power between organized capital and labour. The label "solidaristic" refers to the general goal of wage policies to gradually achieve approximate incomes and to avoid labour market segmentation. Trade unions coordinated their bargaining activities in ways such that "better-earning unions [...] restrained themselves in collective bargaining and wage movements for the benefit of the weakest". ${ }^{27}$ Any remaining wage differences were supposed to mainly reflect differences in skills. Complementing state active labour market polices stimulated, inter alia, geographical mobility and retraining, and were therefore always "supply-oriented". State policies further

25. Mats Benner, The Politics of Growth: Economic Regulation in Sweden 1930-1994 (Lund, 1997), p. 42 .

26. Rune Åberg, "Wage Control and Cost-Push Inflation in Sweden since 1960", in Ronald Dore, Robert Boyer, and Zoe Mars (eds), The Return to Incomes Policy (London, 1994), pp. 7 I-93.

27. Martin Peterson, "Pathways of the Welfare State", in Bengt Larsson, Martin Letell, and Håkan Thörn (eds), Transformations of the Swedish Welfare State: From Social Engineering to Governance? (Basingstoke, 20I I), pp. 23-38. 
included the replacement of industrial jobs with public employment ${ }^{28}$ and wage subsidies for sectors and companies whose survival was under threat as a result of these wage policies.

Many observers emphasized that the conditio sine qua non for this socio-economic development model to function was that "most people are working and have enough income for a high living standard in relative terms, and during temporary periods of unemployment, sickness, and so on, income losses should be compensated to keep people out of poverty". ${ }^{29}$ Not accidently, in European comparison, Swedish governments upheld Keynesian principles in socio-economic regulation the longest. Even during the unstable period of the I970s and I980s, when other European countries changed their policy priorities from fighting unemployment to fighting inflation, Sweden "withheld and even strengthened Keynesian principles by the so-called bridging strategy which, among other things, resulted in state investments in non-profitable industries". ${ }^{30}$ As long as priority was given to the creation of employment, shortages within the labour market were to be avoided by supporting the mobility of workers towards key industries and geographical regions in need of development.

The political priority of creating employment is reflected in comparatively high economic activity rates that fluctuated above eighty per cent during the I970s and I980s. In I991, this indicator, which measures the percentage of the economically active in the population capable of working, ${ }^{3 \mathrm{I}}$ stood at $83.3 \mathrm{per}$ cent. ${ }^{32}$ The unemployment rate stood at 2.9 per cent. Unlike central European countries such as Germany, which mainly recruited male so-called guest workers from southern and south-eastern Europe to meet employers' demands for an increasing workforce during the Fordist upswing while leaving the traditional domestic "male breadwinner" model largely intact, the Swedish state initiated campaigns to recruit women to the workforce as early as the I960s. As a result, women's activity rate exceeded 70 per cent as early as the I970s and stood at $8 \mathrm{I}$ per cent in I99I. ${ }^{33}$ At 2.5 per cent, the rate of female

28. Mattias Bengtsson and Tomas Berglund, "Labour Market Policies in Transition: From Social Engineering to Standby-Ability", in Larsson et al., Transformations of the Swedish Welfare State, pp. 86-103, 86-87.

29. Daniel Larsson and Björn Halleröd, "Sweden: The Impact of Policy and Labour Market Transformation”, in Neil Fraser, Rudolfo Gutiérrez, and Ramón Peña-Casas (eds), Working Poverty in Europe (Basingstoke, 20I I), pp. I I 2-I32, I I3.

30. Ibid., p. I I 4 .

3I. More precisely, it measures the percentage of those in the age range $16-64$, who are either selfemployed, employed, or unemployed but looking for work. Non-active persons include people who for one reason or other cannot or do not want to seek formal employment (including those incapable of working due to sickness or participation in education).

32. Koch, Roads to Post-Fordism, p. 76 (based on International Labour Organization (ILO) data at http://laborsta.ilo.org, last accessed 6 September 20I6).

33. Ibid. 
unemployment was below the overall average. In the same period, the average annual number of hours worked per person in employment remained almost constant, with I,557 hours worked in 1973 and $1,56 \mathrm{I}$ hours in 1990 .

The welfare and social protection system has often been characterized as "social democratic" and "universal" in the sense that the whole population, regardless of socio-economic position, is insured against risks such as illness and old age. In addition, benefits were introduced that were made dependent on the previous employment status. The welfare system was based on egalitarian values and policy goals such as the equal distribution of incomes, low poverty rates, and the ambition to secure income maintenance in cases of unemployment, and universal access to health, care, and education services. ${ }^{34}$ The funding of the system was based on a combination of contributions paid by employers and employees as well as tax revenues. Its two main pillars were a network of encompassing social insurances and an umbrella of social welfare services. Hence, the state not only played a key organizational role in the creation of commodified employment, it also made labour market participation the necessary condition for eligibility for income-related and non-means-tested benefits, especially from unemployment insurance schemes and from sickness, incapacity, and early retirement schemes. From the beginning, the regulating national state was complemented by an important role of the local level, the municipalities. This is especially obvious in the area of minimum income protection (MIP), which mainly takes the form of social assistance. The latter was designed as a means-tested benefit mainly under the responsibility of the municipalities. It was normally claimed if people were either economically active but not entitled to unemployment benefits or economically inactive, for example due to health reasons. The designers of the Swedish welfare state indeed assumed that social assistance would gradually lose significance within MIP as coverage of employment-related insurance would broaden. ${ }^{35}$

Typical for the Fordist period, which dominated the postwar years (I9501975), ${ }^{36}$ the Swedish growth and welfare model included elements of "social engineering" as well as practices of external control and discipline that reflected modernist ideas of top-down government and management philosophies.

34. Mikko Kautto et al., "Introduction: How Distinct are the Nordic Welfare States?", in Idem et al. (eds), Nordic Welfare States in the European Context (London, 200I), pp. I-I 3; Olli Kangas and Joakim Palme (eds), Social Policy and Economic Development in the Nordic Countries (Basingstoke, 2005).

35. Anna Angelin, Håkan Johansson, and Max Koch, "Patterns of Institutional Change in Minimum Income Protection in Sweden and Germany", Journal of International and Comparative Social Policy, 30 (2014), pp. 165-179.

36. Max Koch, Capitalism and Climate Change: Theoretical Discussion, Historical Development and Policy Responses (Basingstoke, 2012), pp. 68-75. 
So-called experts of various kinds - including macroeconomists, sociologists, social psychologists, and pedagogues - played leading roles. The point of view "that 'human problems' needed particular experts [...] was echoed [...] in the idea that the welfare of the new 'people's home' [folkhemmet] was to be built through a reconstruction not only of the 'home', but also through an improvement of the 'people". ${ }^{37}$ The ambition was nothing less than to "develop 'a new human type', more mature than previous, by collective socialization and eugenics". ${ }^{8}$ For Gunnar and Alva Myrdal, leading "experts" in various societal matters of the time and founding parents of the Swedish welfare state, a "full utilization production capacity required a rationally administered population stock, access to subsidized housing in the vicinity of the production sites, free healthcare, child benefits, and institutional education". ${ }^{39}$ What came to be known as "consensus culture" was in crucial parts "engineered" from above and put into practice by the use of a range of disciplining measures. In addition, from the beginning, top-down consensus meant placing emphasis on the "responsibility of the individual" and the ideas that "if society should help, there should be reciprocal obligation to do something in return", thereby addressing the "individual's moral sense of obligation to give something back". ${ }^{4}$

\section{Growth strategy, employment, and welfare regulation after the crisis of the early 1990 s and EU entry}

Sweden's wage determination and industrial relations model appeared to change dramatically in the early r 990 s when a Conservative government came to power whose programme deprioritized full employment in favour of price stability and the reduction of the budget deficit. Policy proposals focused on strengthening the role of company-level wage bargaining and improving the competitive position of the employers. Employers' taxes and contributions were reduced, fixed-term employment contracts were facilitated, and welfare entitlements were cut. ${ }^{{ }^{\mathrm{I}}}$ The period also saw a brief stage of uncoordinated decentralization of collective bargaining, when the employer organization (SAF) withdrew its representatives from tripartite boards in I99I. However, fears that the "Swedish model" would collapse

37. Bengt Larsson, Martin Letell, and Håkan Thörn, "Transformations of the Swedish Welfare State: Social Engineering, Governance and Governmentality", in Larsson et al., Transformations of the Swedish Welfare State, pp. 3-22, I3.

38. Ibid.

39. Ibid.

40. Ulla Björnberg, "Social Policy Reforms in Sweden: New Perspectives on Rights and Obligations", in Larsson et al., Transformations of the Swedish Welfare State, pp. 71-85, 72.

4I. Jonas Pontusson and Peter Swenson, "Labour Markets, Production Strategies, and Wage Bargaining Institutions: The Swedish Employer Offensive in Comparative Perspective", Comparative Political Studies, 29 (1996), pp. 223-250. 
completely did not become reality..$^{42}$ In I 994 , once again it was an engaged state that initiated the reorganization of the wage determination process and wider development strategy. The Social Democratic government, which had been voted back into power, convinced the SAF to return to collective bargaining, which was now to take place mainly at sector level. The Central Bank, which was made formally independent in 1993 but which continued to be linked to the government's positions through the government representatives on the board of the bank, supported sectoral wage developments with a complementary interest rates policy. A further new government method to influence the wage-determination process was the introduction of an "arbitration institute", where all labour market parties were to be represented. This new institution was given the power to intervene in wage bargaining if its outcome was deemed unfavourable for general socio-economic development. Its main function, however, was to create and enforce a common basis for negotiation before actual bargaining rounds began. This new "Alliance for Growth", in which the government had taken the initiative, was geared towards the technological upgrading of Swedish industry. ${ }^{43}$ Its main features included state support of sectoral innovation systems in existing areas of industrial specialization and research into promising technologies such as telecommunication, pharmaceuticals, biotechnology, and the information sector. Various policies for upgrading regional industrial and technological capacity were developed. At the same time, the institutional infrastructure was improved by establishing clusters that brought together regional actors and organizations. This was complemented by training and retraining programmes for staff and an expansion of the educational system.

This "high road" of competing within increasingly transnational markets was also the strategy with which Sweden joined the European Union in I995. Subsequently, the country became subordinated to EU regulations in various policy fields as well as part of European labour market policies, such as the EES. For a long period, and not only in Sweden, the launching of a European employment policy, and indeed a European Social Model, had been regarded as conflicting with national traditions, and it was also seen as an obstacle to the achievement of competitiveness through market liberalization. ${ }^{44}$ In the course of the 1990 , however, this perception was reversed and European employment initiatives were no longer perceived as an obstacle to growth and development but, on the contrary, as one of their

42. Koch, Roads to Post-Fordism, pp. 84-88.

43. Mats Benner, "The Scandinavian Challenge: The Future of Advanced Welfare States in the Knowledge Economy”, Acta Sociologica, 46 (2003), pp. I 36-I 49.

44. Frank Deppe, Michael Felder, and Stefan Tidow, "Structuring the State - The Case of European Employment Policy", in Beate Kohler-Koch (ed.), Linking EU and National Governance (Oxford, 2004), pp. 175-200. 
structural preconditions. ${ }^{45}$ Domestic employment regimes were opened up to new practices and strategies designed at European level and the link between economic and social policies was tightened, above all, through an integrated "activation" approach to welfare policies. Benchmarking of employment policies became a legal obligation across the EU, with the aim of achieving greater convergence in the goals of employment policy. ${ }^{46} \mathrm{EU}$ employment policy goals took the form of several "Integrated Guidelines", particularly aiming at the creation of more jobs both as standard and nonstandard employment. ${ }^{47}$

Within this rescaled employment regulation, the operation of "soft" governance techniques came to predominate over "hard" laws. The EU applies the Open Method of Coordination (OMC), an iterative procedure, involving a "rolling programme of yearly planning, monitoring, examination and readjustment" whereby, in the case of the EES, "national employment policies are put to the test of cross-country comparison, including peer review".$^{8}$ A range of quantitative targets were specified around these pillars that EU member states were supposed to achieve in three-year National Reform Programmes. The European emphasis on "employability" and the corresponding employment guidelines stress the self-responsibility of citizens. In a sort of new social contract, it is the individual's duty to look for work and to improve his or her adaptability to the demands of the labour market, while the state not only encourages the "return to the labour market of those inactive persons willing and able to take up a job" 49 but also cuts or abolishes the unemployment benefits of those who are not willing to do so. This fitted nicely with the Swedish Social Democrats' focus on people's working capacities and motivations to improve their labour market prospects. Coinciding with Sweden's accession to the EU, its employment discourse shifted from "lack of employment" (implying demand-oriented measures) to "lack of employability" (implying supply-oriented measures). ${ }^{50}$

During the 1994-2006, Social Democratic government austerity measures to lower the budget deficit were combined with the ambition to transform Sweden into a "leading knowledge-nation". SI Accordingly, the

45. Max Koch, "The State in European Employment Regulation", Journal of European Integration, 30 (2008), pp. $255-272$.

46. Paul Teague, "Deliberative Governance and EU Social Policy", European Journal of Industrial Relations, 7 (200I), pp. 7-26.

47. Julia S. O'Connor, "Non-Standard Employment and European Union Employment Regulation", in Max Koch and Martin Fritz (eds), Non-Standard Employment in Europe:

Paradigms, Prevalence and Policy Responses (Basingstoke, 20I3), pp. 46-66.

48. Marginson and Sisson, European Integration and Industrial Relations, p. 95.

49. Deppe et al., "Structuring the State", pp. I75-200, I 88.

50. Bengtsson and Berglund, "Labour Market Policies in Transition", p. 87.

s. Ibid., p. 90. 
"work strategy" (arbetslinjen), designed to bring as many people as possible into employment, was complemented with a "competence strategy" (kompetenslinjen) and lifelong learning was "championed as necessary to maintain full employment in the future". ${ }^{2}$ As a corollary, state investment in higher education expanded in order to increase the employability and competitiveness of the Swedish workforce. The compulsory schooling age was increased to nineteen, and the number of students at university doubled in comparison to the late I980s. In the same period, however, "activation" policies began to be applied more strictly, mainly in the form of "economic pressures through unemployment insurance", but also through the involvement of the unemployed through "action plans" or, more generally, the contractualization of relations between an unemployed individual and the employment office. Obligations for citizens to take responsibility for supporting themselves were increased both in discourse and policies, while the role of the state as direct employer became less pronounced. However, the fact that the Social Democrats reversed some of the Conservative reforms in labour market and welfare regulation ensured trade union support. While maximum unemployment benefits were reduced twice, active labour market policies were expanded during the crisis of the I990s, with five per cent of the labour force being temporarily employed in job creation programmes. ${ }^{53}$ Further welfare reforms included a reduction in the generosity of the social insurance system (introduction of fees, individual contributions, waiting days as well as a general lowering of replacement rates), a reform of the pension system to reduce costs and to increase the supply of labour by basing pensions on lifelong employment, and also savings in health and social services expenditure.

The Centre-Conservative government, in power from 2006 to late $20 \mathrm{I} 4$ when it was replaced by a Red-Green minority government, continued the "supply-oriented" growth and employment strategy in many ways but particularly stressed "social exclusion" (utanförskapet) within the "work strategy" in order to raise the incentive to work and to increase the labour supply. Hence, "social exclusion" began to be used largely synonymously with "unemployment". Accordingly, labour market programmes were "reduced, shortened and individually adapted", while more of the Public Employment Service's resources were invested in matching and placement. ${ }^{54}$ Prime targets of government reforms were sickness and unemployment insurance. Sickness insurance benefits became subject to stricter rules and "work tests", while the duration of eligibility was shortened. The formal replacement rate for unemployment insurance decreased

\section{Ibid.}

53. Anders Björklund, “Going Different Ways: Labour Market Policy in Denmark and Sweden”, in Esping-Andersen and Regini, Why Deregulate Labour Markets? pp. I48-i 80, I 57.

54. Bengtsson and Berglund, "Labour Market Policies in Transition", pp. 92-93. 
to a maximum of seventy-five per cent of the former employment-related income, with direct effects on the actual replacement rate individuals received. Interpretations and applications of the work requirement became generally stricter. Unemployed people had to be "prepared to take a job nationally from the first day of being registered at the employment office", 55 while the receipt of unemployment benefits was reduced to a maximum of 300 days. For Ferrarini et al. the overall outcome of these reforms was that the income protection system had fallen from grace. ${ }^{56} \mathrm{In}$ comparison to other OECD countries, these authors demonstrate that Sweden features slightly higher replacement rates through sickness insurance than the OECD average, yet lower replacement rates through unemployment insurance. A further crucial change concerned the drastic increase (from 99 to 344 kronor in 2007) in the membership fee to the unemployment insurance funds, which are administered by the unions. ${ }^{57}$ This led to an increase in the number of people opting out of these funds and of trade union representation in general. Gaps between the employed and unemployed grew further through the Job Tax Deduction (jobskatteavdraget), which increased the income of the employed relative to that of the unemployed.

Arbetslinje as a political priority is reflected in the still high overall economic activity rate of 75.4 per cent in $2000 .{ }^{58}$ The decrease since I99I is mainly down to lower activity rates among younger and older people (3 I per cent among people I6-I 9 and 52 per cent among people 60-64). The unemployment rate stood at $4 . \mathrm{I}$ per cent in 2000 . By 2008 , the activity rate among people aged I6-64 had increased again to 79.5 per cent, and the unemployment rate had risen to 6.7 per cent. In addition, 17.2 per cent of those aged 65-69 and 6. I per cent of those 70-74 were economically active. Women's activity rate stood at 73.I per cent in 2000 and unemployment at 4.3 per cent. Also, the activity rate among women aged I $6-64$ rose to 77.2 per cent in 2008. About I 2.6 per cent of women aged $65-69$ and 3.2 per cent of those aged 70-74 were economically active. Unemployment stood at 7 per cent in 2008. The average annual number of hours worked per person in employment was 1,642 in 2000 and 1,617 in 2008 , higher than in the 1970 s and I980s. Hence, the long-term trend towards a reduction

55. Ibid., p. 99.

56. Tommy Ferrarini et al., Sveriges socialförsäkringar i jämförande perspektiv. En institutionell analys av sjuk-, arbetsskade- och arbetslöshetsförsäkringarna $i$ I8 OECD-länder 1930 till 20I0, Underlagsrapport till den parlamentariska socialförsäkringsutredningen (S2010:04) (Stockholm, 2012).

57. In Sweden, it is not obligatory to join an unemployment insurance scheme, unlike, for example, in Germany.

58. All employment-related data in this paragraph are taken from the ILO at http://laborsta. ilo.org. The data on hours worked per person in employment are taken from the OECD at http://stats.oecd.org/index.aspx?DataSetCode=ANHRS. 
in the length of the working day that had characterized capitalist development in the core countries since the industrial revolution came to a halt in Sweden.

Respondents in a recent study of the Swedish minimum income system ${ }^{59}$ pointed out that the increase from 211,000 in 2007 to 247,000 in $2010^{60}$ in the number of households on social assistance was due not only to the global financial crisis and its employment impacts, but also to retrenchment in sickness and unemployment insurance, as a result of which a significant number of clients were transferred to the social assistance system. ${ }^{61}$ Salonen's research report concludes that between 60 and 80 per cent of recipients could be lifted out of social assistance if these neighbouring social security systems were reformed accordingly. ${ }^{62}$ Interviewees in Angelin et $a l .{ }^{63}$ pointed out that social assistance would receive excessive significance for the unemployed and those with health impairments and that a substantial proportion of clients should instead be covered by other types of welfare. There is, furthermore, evidence that what was originally thought to be a form of short-term support for people in need is becoming a long-term source of income. The average duration for the receipt of social assistance increased from 4.3 months in 1990 to 6.6 months in $20 \mathrm{II}$.

Reflecting developments in the EU agenda on active inclusion and previous shifts towards an active welfare state, Sweden's MIP system and the social assistance system in particular underwent a transition from an emphasis on collective rights, redistribution, and an understanding of poverty as a structural issue to an emphasis on workfare, employability, and the interpretation of poverty and exclusion as individual and attitudinal problems. Status guarantees, the degree to which an individual's position is determined and safeguarded by past efforts without means testing, have been diminished or suspended in order to trigger swift adaptions to market swings. ${ }^{64}$ Indeed, both Social Democrats and Conservatives tend to avoid the term "poverty", including the poverty-related EU 2020 benchmarks, and have instead moved the notion of social exclusion (utanförskap) into focus. According to the new discourse, every citizen who was either on benefits or unemployed is considered "excluded". Yet, rather than linking social exclusion to the distribution of income and to address it as a structural

59. Anna Angelin et al., The National Arena for Combating Poverty: National Report Sweden (Lund, 2013), pp. I7-I 8.

6o. Tapio Salonen, Det nödvändiga uppbrottet - reformera det ekonomiska bistaindet (Stockholm, 2013).

6r. This fourteen per cent increase in social assistance uptake was reflected in municipalities' expenditure.

62. Salonen, Det nödvändiga uppbrottet.

63. Angelin et al., The National Arena for Combating Poverty, pp. I7-18.

64. Angelin et al., "Patterns of Institutional Change in Minimum Income Protection", pp. 165-I79. 
phenomenon, ${ }^{65}$ the Conservative governments, in particular, began to define exclusion as a matter of labour market participation only. Accordingly, it mixed traditional norms of the welfare state with a redefined work ethic and put stronger emphasis on individual duties, while even mention of the term "poverty" was avoided as much as possible. ${ }^{66}$

\section{CONCLUSION}

The state plays indispensable roles in capitalist development, spatial targeting, and in shaping labour relations and welfare. The spatial dimension of state regulation is subject to descaling and rescaling processes, during which new, multi-scalar structures of state organization, political authority, and socio-economic regulation emerge. The state retreats from one sphere (for example, from public ownership and national regulation of labour markets) only to enter and re-regulate other spheres and domains (for example, in its new role as "benchmarking" and "advising state" and as an actor at the European level). The developing steering role of the state constitutes a new form of "intervention" as the state provides support for actors to assimilate some of its roles and to work in partnership with them in novel and strategic ways. Particularly in the context of the EES, it defines criteria in relation to what it sees as good practice. The interpretations of state roles in employment and welfare regulation have changed accordingly.

While the state as employer is important in both periods, its role as direct employer has diminished significantly. At the same time, however, its role as indirect employer, especially as organizer of public-private partnerships, increased. As arbiter in intermediating corporatist/neo-corporatist processes and managing macroeconomic processes, governments combined "demand" and "supply" policies in the form of Keynesian economic and employment policies with active labour market polices in the postSaltsjöbaden period. In the post-EU-accession period, the demandsupporting role decreased significantly, while governments saw their main raison d'être in improving Sweden as a location in European and global competition; that is, the supply side. State welfare policies saw a transition from decommodification of labour power and redistribution in the classical Social Democratic welfare regime, ${ }^{67}$ in which inequality, unemployment, and poverty were regarded as structural issues, towards an emphasis on recommodification of labour power and workfare, in which, not unlike the

65. Paul Littlewood et al. (eds), Social Exclusion in Europe (Aldershot, 1999).

66. A related theme on the government's agenda that interviewees in the above report by Angelin et al. from 2013 stressed is the increased focus on "cheating", "scrounging", and benefit misuse and a generally more restrictive attitude towards and increasingly moralizing view on benefit recipients' needs.

67. Esping-Andersen, The Three Worlds of Welfare Capitalism. 
Table I. State roles in economic, employment, and welfare regulation in the post-Saltsjöbaden (1938) and post-EU-accession periods

\begin{tabular}{|c|c|c|}
\hline & After Saltsjöbaden & After the crisis of the 1990s and EU accession \\
\hline Policy goals and outcomes & $\begin{array}{l}\text { Collective rights and redistribution and an } \\
\text { understanding of poverty as a structural issue }\end{array}$ & $\begin{array}{l}\text { Strengthened workfare ethic, employability, and } \\
\text { the interpretation of poverty and exclusion as } \\
\text { individual problems }\end{array}$ \\
\hline Industrial relations/wage bargaining & National level & Sector level \\
\hline Employment & $\begin{array}{l}\text { Full employment plus active labour market } \\
\text { policies }\end{array}$ & Full employment plus workfare \\
\hline Welfare & $\begin{array}{l}\text { Creation of a universal system that insures the } \\
\text { population against social risks built on } \\
\text { insurance plus social assistance as last resort of } \\
\text { MIP }\end{array}$ & $\begin{array}{l}\text { Cuts in unemployment and sickness insurance led } \\
\text { to change in role of social assistance towards a } \\
\text { permanent (and inadequate) means of MIP }\end{array}$ \\
\hline \multicolumn{3}{|l|}{ State roles } \\
\hline Spatial target & National plus local & European, national plus local \\
\hline Employer & Emphasis on creation of direct employment & $\begin{array}{l}\text { Decreasing role as direct employer; greater } \\
\text { pervasiveness of state influence, e.g. in the form } \\
\text { of public-private partnerships }\end{array}$ \\
\hline $\begin{array}{l}\text { Arbiter in intermediating corporatist / } \\
\text { neo- corporatist processes and } \\
\text { managing macroeconomic } \\
\text { processes }\end{array}$ & $\begin{array}{l}\text { Active state role in bringing about Saltsjöbaden; } \\
\text { support of growth strategy through } \\
\text { complementary labour market and welfare } \\
\text { policies }\end{array}$ & $\begin{array}{l}\text { Loss of national regulatory power due to EU } \\
\text { accession partially compensated through } \\
\text { representation in EU bodies; active role in } \\
\text { rebuilding industrial relations based on sector- } \\
\text { level wage bargaining }\end{array}$ \\
\hline Guarantor of employment rights & Emphasis on collective rights & $\begin{array}{l}\text { Emphasis on individual rights and duties and } \\
\text { disciplinary aspects within the "work strategy" }\end{array}$ \\
\hline Redistributor and welfare state & $\begin{array}{l}\text { Emphasis on decommodifying labour power; } \\
\text { social engineering }\end{array}$ & $\begin{array}{l}\text { Emphasis on recommodifying labour power and } \\
\text { creating self-regulating, self-supporting, and } \\
\text { self-disciplining employees and welfare } \\
\text { recipients }\end{array}$ \\
\hline
\end{tabular}


classical liberal regimes, MIP and not income redistribution and the limitation of social inequality is in focus.

Reflecting recent European employment discourses, unemployment, inequality, and poverty are today largely regarded as individual problems, for which individual "solutions" are provided - normally at the local level and in the form of activation contracts. Far from weakening or "withering away", the Swedish state continues to "engineer" socio-economic regulation, labour regimes, and employment, and there is also continuity in its use of coercive traits, particularly in its application of arbetslinje. Yet, there has been a transition from clear-cut top-down government towards a governance regime in which the execution of state power is much less obvious and where much of the disciplining work has been shifted from external state authorities to and incorporated by individual employees and welfare recipients - a shift in the governmentality of employment and welfare that scholars such as Goul Anderson et al. ${ }^{68}$ and Larsson et al. ${ }^{69}$ theorize in Foucauldian terms. Indeed, the individualized, self-regulating, self-supporting, and self-disciplining entrepreneurial employee who typifies the current labour regime makes for a much improved "economy of power" than the collectively organized and class-aware worker of the postSaltsjöbaden period.

68. Jorgen Goul Andersen et al. (eds), The Changing Face of Welfare: Consequences and Outcomes from a Citizenship Perspective (Bristol, 2005).

69. Larsson et al., Transformations of the Swedish Welfare State. 